\title{
Trade and Value Chain Governance of Large Cardamom in Nepal
}

\section{Sushil Chandra Sapkota*}

Faculty of Agriculture, Agriculture and Forestry University (AFU), Rampur Chitwan, Nepal

*Corresponding Author: Sushil Chandra Sapkota, Faculty of Agriculture, Agriculture and Forestry University (AFU), Rampur Chitwan, Nepal.

Received: May 30, 2019; Published: July 15, 2019

DOI: $10.31080 /$ ASAG.2019.03.0575

\begin{abstract}
Large cardamom (Amomum subulatum Roxburgh.) is an important high value spice crop having high potential cultivated mostly in the Eastern Himalayan regions of Nepal, Bhutan and few Indian states. Large cardamom is found to be used in foods, beverages, and has enormous medicinal values. In Nepal, Ilam, Panchthar, Sankhuwasabha and Taplejung are the major cardamom producing districts. About 73\% of total national production still comes from these four districts. Major cultivars of large cardamom grown in Nepal are Ramsai, Golsai, Chibesai, Dambersai, Sawney and Kanti daar. Trade is a complex phenomenon involving selling and buying of goods and services between two or more parties in consideration of cash and cash equivalents. Large cardamom has been the main exportable commercial crop since 1960s, and has contributed 2.25 percent in the total export from Nepal during 1974/75 to 2014/15. The contribution was further extended to more than 4\% during 2010s. According to Ministry of Agricultural Development, in 2013/14, it is grown in 40 districts which occupy 14,847 hector with productive area of 11,501 hector and produces 5,225 MT with productivity of $0.45 \mathrm{MT} / \mathrm{Ha}$. Cardamom makes it's more than $90 \%$ of its sales to India without value addition. Due to non-existence of any central marketing facility or an auction market in the country, the price of the commodity is dictated by the terminal markets in India and local farmers including DADOs and LCEAN. Shortcomings in Nepalese cardamom production are remaining for insufficient saplings supply; large ageing of shading plants, lack of research outputs and quality based improved dryers. Weaknesses are also seen in marketing and trade as lacking of Auction Market, ware house, suitable brandings, equipped quarantine laboratory as well as organized trading systems are importantly exist. Similarly, it bears a huge possibilities in terms of climatic suitability and sufficient land availability.
\end{abstract}

Keywords: Large cardamom, trade, value chain, governance, agriculture

\section{Abbreviations}

GON: Government of Nepal; MOAD: Ministry of Agriculture Development; HS: Harmonized System; DADO: District Agriculture Development Office; LCEAN: Large Cardamom Entrepreneur's Association of Nepal; WTO: World Trade Organization; MT: Metric Ton.

\section{Introduction}

Background

Large cardamom (Amomum subulatum Roxburgh.) is an important high value spice crop having high potential, cultivated mostly in the eastern Himalayan regions viz. Nepal, Bhutan and few Indian states. Large cardamom is a perennial herbaceous spice crop of family Zingiberaceae family, which is known as Alainchi in
Nepali and renounced as Black Gold, Queen of Spices. It is widely used in foods, beverages, perfumes and having enormous medicinal value [1]. This spice is the world's third most expensive after saffron and vanilla.

In Nepal, Ilam, Panchthar, Sankhuwasabha and Taplejung are the major cardamom producing districts. About $73 \%$ of total national production still comes from these four districts [2]. It is believed that large cardamom was introduced in Nepal (Ilam) in 1865, by Nepalese laborers who went to Sikkim for seasonal work [2]. However, planned development of large cardamom was found to be started after establishment of Cardamom Development Centre at Fikkal, Ilam district in 1975 [2]. Major cultivars of large cardamom grown in Nepal are Ramsai, Golsai, Chibesai, Dambersai, 
Sawney and Kanti daar. Among these, Ramsai, Golsai and Chibesai are widespread in cultivation and export.

Trade is a complex phenomenon involving selling and buying of goods and services between two or more parties in consideration of cash and cash equivalents whose primary aim is to satisfy the needs of both seller and buyer. India is the main destination for Nepal's exports and also main competitor in the world market. For supply chain, there were found to be lack of traders. All most all are acting as collector either local or regional and they handover the collected large cardamom to Indian traders. This is the main cause behind the diversion of large cardamom to India. There were found to be some sorts of initiatives for drying either by traditional method or by improved smokeless dryer. Nonetheless, the understanding over two types of dryers was not found to be common among all farmers and collectors. Besides farmers, collectors were also found to be unaware of WTO and SPS measures. They have not analyzing market either due to several reasons.

Similarly, value chain governance is the authority and power relationships that determine how financial, material, and human resources are allocated and flow within a chain. It determines who is the major power driver (lead firm) within a value chain and who is the power driven.

Large cardamom has been listed as one of the most potential crop for export in Nepal Trade Integration Strategy 2010 (NTIS 2010). NTIS 2010 has used four indicators to rank the commodities. First is current export performance. Second is a current demand condition for the given goods, using a composite indicators of importing markets, growth rates of the markets, and tariff advantage or disadvantage for Nepalese exporters. Third is measure of domestic supply capacity. Final indicator is measures of the potential socioeconomic impact of the sector including fulltime equivalent employment, participation of women in the sector, impact on poor regions, and impact on skill development. Large Cardamom is categorized as high in first indicator: Export performance, low in second indicator: World Market Condition, high in third indicator: Domestic Supply Condition, medium in fourth indicator: Socioeconomic impact and high in overall export potential [2].

\section{Rationale}

Large cardamom bears a huge potential in terms of its commercialization and trade. Instead of potentialities this sector couldn't make expected progress due to several bottlenecks on its way of cultivation, management, storage, processing and marketing. I believe that, my study on the trade and value chain governance of large cardamom would help pointing out those typical problems and the possible ways out of it.

This study would be able to identify the existing trade markets, value chains and value chain governance system. It would help find out the problems faced by growers, collectors, processors, wholesalers and retailers and the power driving and power driven stakeholders of large cardamom trade and commerce. Similarly, it would be fruitful to suggest the good trading activities and governance activities for the better production and marketing of large cardamom.

\section{Objectives}

General objectives

- To assess the information about the trade and value chain governance of large cardamom in Nepal

\section{General objectives}

- To know about the value chain route of large cardamom in and out of Nepal

- To know about the value chain governance authority in $\mathrm{Ne}$ pal

- To know about the production and marketing of large cardamom in Nepal

- To know about the status of farmers involved in the large cardamom production and trade

- To suggest farmers about the effective routes of large cardamom trade.

\section{Literature Review}

Large Cardamom is one of the important cash spice crop of Nepal. Global trade of large cardamom is difficult to trace due to the absence of unique HS code at six-digit level [3]. The HS code of large cardamom is 09083010 [2]. Large cardamom has been the main exportable commercial crop since 1960s, and has contributed 2.25 percent in the total export from Nepal during 1974/75 to $2014 / 15$. The contribution was further extended to more than $4 \%$ during 2010s [4]. According to Ministry of Agricultural Development, in 2013/14, it is grown in 40 districts which occupy 14,847 hector with productive area of 11,501 hector and produces 5,225 MT with productivity of $0.45 \mathrm{MT} / \mathrm{Ha}$. Development region wise, central development region has highest productivity of $0.61 \mathrm{MT} /$ Ha followed by Eastern Region which possesses productivity of $0.45 \mathrm{MT} / \mathrm{Ha}$. In case of total production, Eastern Region produces 4,907 MT which is $93.91 \%$ of total production [2]. 
Cardamom makes it's more than $90 \%$ of its sales to India without value addition. The Large Cardamom produced in is exclusively sold to Indian markets (Siliguri). Delhi and Amritsar are the potential markets in. After reaching India, the large cardamom is value added and sorted to export abroad. The typical market channel is:

Collector - District Traders - Regional Trader - Indian Traders Export to third countries [5].

Due to non-existence of any central marketing facility or an auction market in the country, the price of the commodity is dictated by the terminal markets in India [6].

\section{Methodology}

Extensive secondary literature survey was done. A desk study and review was conducted, collecting existing data and trade mapping from varieties of already prepared research articles and other publications from the online surfing.

\section{Key Findings}

- In terms of use: As mentioned in [1], large cardamom is of high value and has several uses as in foods, perfumes, beverages, medicines, etc.

- In terms of Opportunities and bottlenecks: Opportunities for cardamom industry are found to be multi-dimensional and potential in many aspects. Such potentialities have been laying in expansion of cardamom land area with waste land too. Productivity gap is still very high could be improved. Strengths of Nepalese cardamom industry have been realized by its suitability in climatic conditions, virgin land availability, and utilization of underused land in production side. In trade side, economic volume of scale, assured nearby markets and fetching up good price are the main forces. Shortcomings in Nepalese cardamom production are remaining for insufficient saplings supply; large ageing of shading plants, lack of research outputs and quality based improved dryers. Weaknesses are also seen in marketing and trade as lacking of Auction Market, ware house, suitable brandings, equipped quarantine laboratory as well as organized trading systems are importantly exist [2].

- In terms of Power Drive: From the literature review it was found that there is not any central power driving body in the trade and commerce of large cardamom. Several local farmers' groups, co-operatives, DADOs and Large Cardamom Entrepreneurs' Association of Nepal are some of the national power driving bodies. Besides, demand from the markets of neighboring country, India also plays a vital role is driving the powers in value chain of large cardamom as major value adding activities are performed in India which later supplied to other countries as Nepalese cardamom is preferred over the Indian large cardamom.

- Suggestions: Instead of high potentialities we haven't achieved desirable output and outcome from the large cardamom. So, the above mentioned obstacles or weaknesses need to be sought for gaining the expected pace of growth in this sector. For this, first of all the farmers need to be made well aware of the possible benefits from cardamom production and they must be trained for sustainable farming plans including cultivation practices, management ideas and methods and processing techniques.

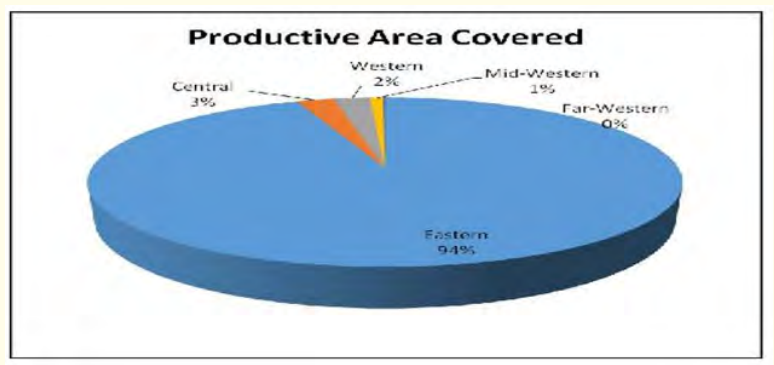

Diagram 1: Productive Area of Cardamom.

(Adopted from Statistical Information on Nepalese Agriculture 2013/2014, Ministry of Agricultural Development)

Production and Yield of Large Cardamom

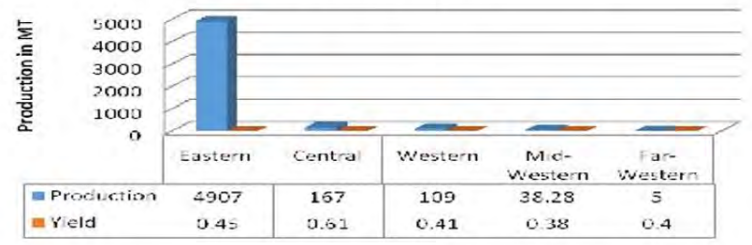

Diagram 2: Production and yield of Cardam.

Adopted from Statistical Information on Nepalese Agriculture 2013/2014, Ministry of Agricultural Development 


\section{Conclusions}

At the same time, the must be Public-Private Partnership for sustainability of cardamom commercialization at various levels especially marketing and price fixing such that farmers won't have to suffer the lower price of produce. Similarly, government must bring into implementation the formulated policies and programs for the development of this sub-sector.

\section{Bibliography}

1. Bhutia PH., et al. "Post harvest and value chain management of large cardamom in hills and uplands". International journal of chemical studies (2018): 505.

2. GON AP. Trade flow analysis of large cardamom in Eastern region (2015).

3. The International Trade Center. Nepal National Sector Export Strategy: Large Cardamom (2017-22) (2017).

4. Ministry of Agricultural Development (MOAD). "Statistical information on Nepalese agriculture 2014/15". Economic journal of development issues 21 and 22 (20102,2015(a)).

5. Kafle B. Cardamom farming in Nepal. Nepal (2013).

6. Timsina K., et al. "Value chain analysis of Cardamom (Ammomum subulatum Rox.): A case study of Taplejung district". Agriculture Development Journal 9 (2012): 29.

Volume 3 Issue 8 August 2019

(c) All rights are reserved by Sushil Chandra Sapkota. 